\title{
People's Attitude Towards Life Insurance in Pakistan
}

\author{
Muhammad Farooq \\ Assistant Professor, Department of Sociology , Government College University Faisalabad \\ Muhammad Roman \\ Mphil Scholar, Department of Sociology, Government College University Faisalabad \\ Naeem Mohsin \\ Associate Professor, Department of Education, Government College University, Faisalabad \\ Fara Riaz \\ Lecturer, Institute of Rural Home Economics, University of Agriculture Faisalabad \\ Haq Nawaz Anwar \\ Chairperson, Department of Sociology, Government College University Faisalabad
}

\section{Doi:10.5901/mjss.2015.v6n3s2p305}

\section{Abstract}

The present study was designed to measure the people's attitude toward life insurance. This study also explores why the people of Pakistan are reluctant to purchase the policy as a tool to accommodate their financial necessities in their rainy days, and also exposed the important factors behind the smaller ratio of life insurance policies despite of its significance and fringe benefits. The ratio of policy holders in Pakistan was found so small when researcher compared it to the other developed countries. The statistics regarding life insurance portrayed a very little ratio of policy holders even among developing countries. There are some traditional, cultural, and religious causes involved behind the low rate of policy owners in Pakistan. The present research examines the behavior of staff of the insurance company which is considered as a barrier by the community to purchase the policy. Such considerable factors encompassing the whole study analyzed through the quantitative data collected from the insurance company staff, and policy holders in Faisalabad city.

Keywords: Social safety nets, Life insurance, Premium, Policy holder, Barriers in the way of life insurance in Pakistan, Chi Square, and Multiple Linear Regression

\section{Introduction}

The present research has concerned with socio-economic safety nets because the prime area of this study encompasses the life insurance of general public which is related with the study of safety nets. In this context, the life insurance should comprehensively consider a best socioeconomic safety net for public which often and on have a standalone support in the rainy days of their present and future (Ahmad, 2012).

The benefit for the policy owner is "peace of mind", in realizing that insured's death will not bring financial problems for loved ones and dependents. However, it can be a lifeguard for life insurance policy purchaser and dependents. Moreover, death provides no other chance merely life insurance could assist to provide financial protection to the survivor. Most people buy policies to secure their upcoming future of their dependants just in case of their death, whether untimely, accidental, or because of illness. Life insurance expands some sure warranty of financial protection for the dependents in the consequence of the insurance policy purchaser's death. The needy of the policyholders are handed this amount if the insurance premium have been paid on time (Nida, 2012). LIMRA, formerly known as the Life Insurance Marketing \& Research Association, analyze that if the bread earner of a family with dependent children dies, family will merely be able to afford their living expenses for only a few months, and four families in ten would have trouble instantly (Mcmaken, 2012). 


\subsection{Importance of Life Insurance}

Life Insurance consists of a range of advantages as other investment modules have. Financial security is the prime advantage of life insurance. It assists to smooth the progress of economic movements. The premiums are collected from multiple investors by the life insurance companies to gather large funds. Trade and other financial development activities are financed by this money. It is also useful for tax payment reduction. Policy holders can claim income tax exemptions for the payment of premiums amount (Bhartiaxa, 2009). In the present time life insurance could be utilized as an investment alternative, because a security for loan and for other demands also. As a life insurance plan bought inconspicuously with due concern could be regulated to assist the variety of requirements of a policyholder. Nowadays Life insurance has become substantial in a world where pension plans, social security benefits, and family savings turn insufficient to respond the financial demand of the complete family, cover wellness prices or to hold a certain life-style, on the off chance of the death of the worker (Nida, 2012).

Variable life insurance is the mixture of savings aspects of whole life insurance and the traditional protection with the growth potential of investment funds. It is comprised of two different elements: the general account and the separate account. The general account is the insurance provider's reserve account, and it is not assigned to the individual policy. The separate account consists of different investment funds within the insurance company's portfolio, like a money market fund, an equity fund, a bond fund, or some combination of these. Because of this core investment trait, the cash value and death benefit may vary, therefore it is known as "variable life insurance" (Pareto, 2012a).

\subsection{Generally practiced Life insurance policy in Pakistan}

Following is the most common type of life insurance policy by means of people interest and attitude in Pakistan:

Endowment Life Insurance: It is a life insurance agreement proposed to pay a lump sum after a specified term (on its 'maturity') or on death of the policy holder. This policy can be surrendered or cashed in early and the insurance company pays the surrender value to the policy owner by determining the duration of policy and the number of premiums paid by the insured (Gala, 2012). It's a surest method which has the guaranty of cash provision either at a particular time or at death. Under this type of policy, the insurance company pays the sum insured plus bonuses at the end of a specific term or at death of the life insurance policy holder if earlier. Premiums are payable under endowment life insurance policy for the specified numbers of year or till death, if earlier. Under this plan, the benefits can be more enhanced by attaching supplementary covers (SLIC, 2012). Term and endowment both type of life insurance policies are based on a specific term but cash value is not involved in term life insurance. Return of premium term life insurance is same like endowment life insurance to a large extent that refunds all of the premiums to the policy holder at the end of term, without considering the death of insured. It offer cash surrender values if the insured doesn't die. This type of policies are available in 15, 20, or 30-year term (Aggarwal, 2005).

Life Insurance Overview and Statistics in Pakistan: There is friendly system for insurance business in developed countries but in Pakistan people are living with the conservative thoughts. The GDP of Pakistan is contributed only $0.23 \%$ by the insurance industry. It is highest in Luxembourg where the contribution is $54.42 \%$. Total Premium of Pakistan insurance industry was $\$ 949$ million in 2006, whereas in India it was \$ 43,032 million. The World Insurance Market premium has increased by $75 \%$ in last 10 years, but Pakistan insurance industry's growth is more than $900 \%$ (Mesum, 2008).

Pakistan is one of the largest countries with the population of 165 million and the majority of people i.e. $97 \%$ are Muslim. People have rigid religious beliefs; and hesitate to buy policy. About $67.5 \%$ of population is living in rural societies and $73.6 \%$ are living below the poverty line (GOP, 2011). As a consequence of less income, low rate of literacy jointly with strict religious beliefs, insurance industry in Pakistan could not develop as compared to other countries of subcontinent e.g. Sri Lanka and India. Historically, insurance industry in Pakistan has been characterized by inadequate and ineffective supervision, inadequate financial and prudential regulations, lack of innovative insurance products and monopoly of state owned insurance companies. The asset structure has been highly skewed towards state owned insurance companies. In 2001, State Life Insurance Corporation (SLIC) and National Insurance Company Limited (NICL) constituted $80.5 \%$ of the total assets of the whole insurance industry. Till 2005 , this share remains $74 \%$ of the total insurance market (Akhter, 2009). The Express Tribune's analysis suggests that in Pakistan, total number of policy holders was about 13.6 million in 2011 , or about $7.8 \%$ of the total population. It is a small number of insured persons but it is rising steadily: it was only $5.9 \%$ in 2006 . According to the data provided by the State Life Insurance Corporation and the State Bank of Pakistan, numbers of people with life insurance in Pakistan have grown of $8.3 \%$ per year for the previous 05 years (Tirmizi, 2012). 


\subsection{Barriers in purchasing life Insurance policy in Pakistan}

The barriers in purchasing a life insurance policy can generally categories in two ways.

1 - Community related barriers

2 - Barriers regarding Company policies and staff behavior

The general public feels uncomfortable while purchasing a life insurance policy because of some important factors as:

- According to the view of people, purchasing life insurance is a "regular" expense. When something is considered as an expense, generally the public avoid having that thing. A person who purchases policy can't enjoy the benefits of life insurance before the completion of the tenure of the policy. In this situation he/she may feel paying premiums as an expense.

- Another important issue that causes the community to become away from purchasing the life insurance policy is that they don't have trust on insurance companies regarding payback of their premiums at the end of policy (Ahuja, 2012).

- A large proportion of community has some specific religious beliefs about the authenticity of life insurance in terms of Islamic thoughts that leads towards an investment of interest and markup, which makes them hesitate to purchase the life insurance policy.

- The limited financial condition of the community also plays a key role in purchasing a life insurance policy, some of them generally wish to secure their future but due to their financial conditions and some other more important requirements get them away from purchasing a life insurance policy.

- Less awareness about life insurance plans may be considered as a barrier in purchasing a life insurance policy, a reasonable proportion of community is actually unaware of real benefits and privileges that they could get by purchasing life insurance policy.

- Education level of common community is not as high as to understand the perks of life insurance policy accordingly (Sigma, 2006).

\subsection{Barriers regarding Company policies and Staff Behavior}

Policies of insurance company and its staff's behavior are absolutely considerable barriers of purchasing life insurance policy by the community.

- Insurance companies have complicated rules and regulations in terms of the understanding of general public as they could not able to approach the actual status of life insurance policy.

- Insurance companies in Pakistan actually depend upon their field force to communicate about all its insurance policies and to deliver all information regarding life insurance plans. Most of the time the field force staff provide fake information to the policy holder. The insurance companies generally have no such criteria of hiring their field force employees in terms of certain level of education, training and experience. The overall reliability on the field force staff with less educational background makes most of the community anxious from the insurance policies.

- Insurance companies in Pakistan have no such system of delivering awareness through seminars, workshops and other modern state of the art methods and tools which may attract all levels of community towards their life insurance policies.

\section{Objectives Of The Study}

The main objective of the study is to investigate and analyze the people attitude towards life insurance.

- To dig out the features and benefits of life insurance

- To examine the factors for hesitation to purchase life insurance policies

\section{Materials and Methods}

The methodological techniques and ways of analyzing the observations play a significant role in social research. Social scientists have commonly been using comprehensive sociological approach and advance techniques in social research in the modern era. Social scientists now use the sophisticated methodological tools and techniques in social research. 
Therefore, methodology is a frame for researcher. Methodology is actually a conceptual sketch or it is the way that how to collect and analyze the information. For the collection and analysis of data quantitative research techniques were used in this study. For the achievement of this purpose well organized methods are applied that express the population characteristics, determine the variation, and predict casual relationship among the variables. The under investigation issue was conducted in Faisalabad City. Multistage sampling technique was applied to draw the sample. At first stage four towns namely Madina Town, Jinnah town, Iqbal town and Lyallpur town were being taken by researcher as universe. At second stage the population of selected towns is divided in three stratums, 1- Policy holders 2- General public 3Marketing staff of insurance company according to the factors behind the attitude of community towards life insurance and the level of efforts by the marketing staff of insurance company within the community. At third stage researcher gathered information of policy holders and marketing staff from zonal office of the insurance company for concerned towns of Faisalabad city as a sampling frame and draw the sample of 200 respondents from both policy holders and marketing staff (140 from policy holders and 60 from marketing staff) by using simple random sampling technique from sampling frame.
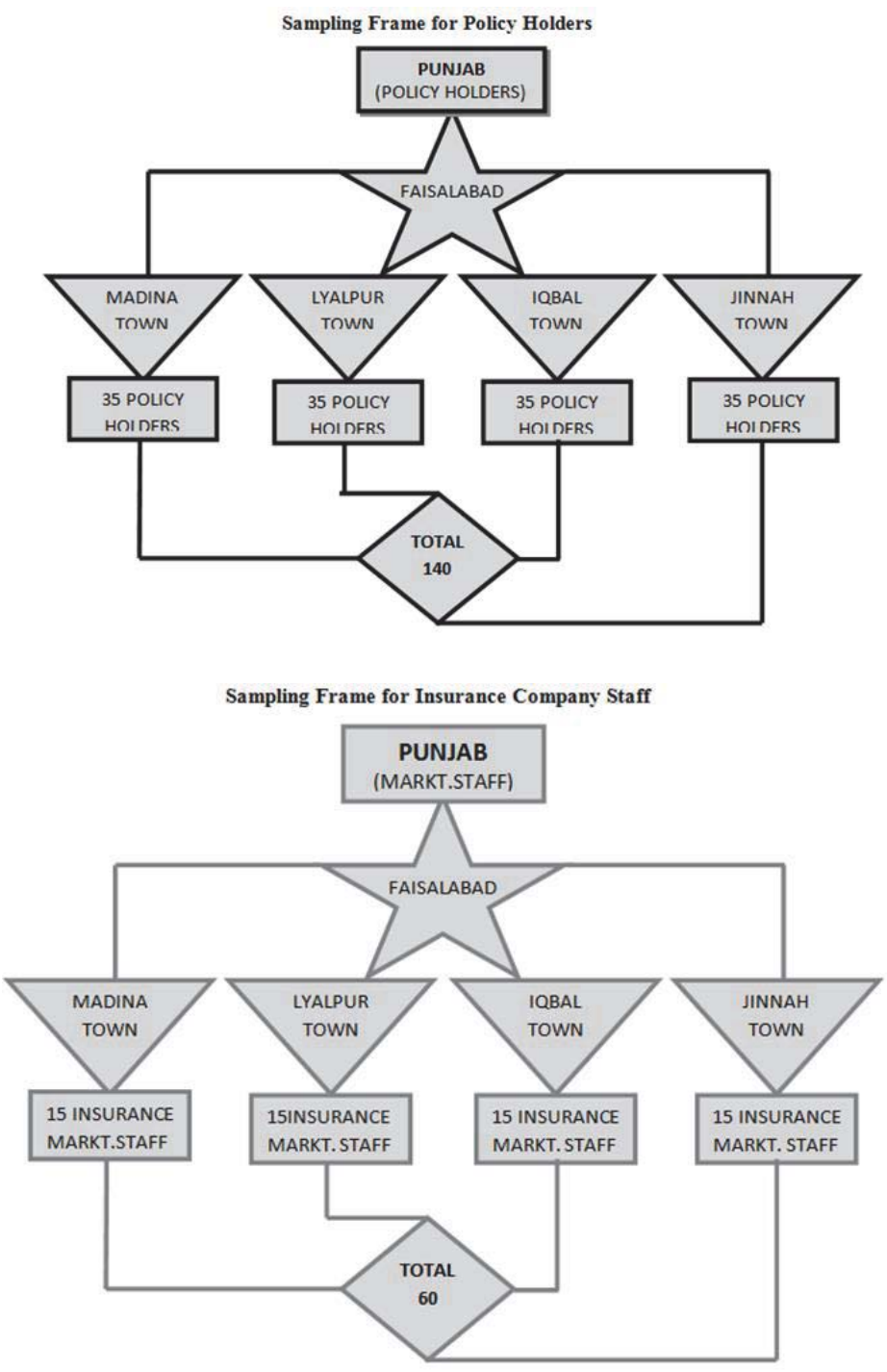

\subsection{Statistical Techniques}

Bivariate analysis was used to explain the relationship between two variables. Pearson Chi-square and gamma statistics were used for this purpose.

Chi-Square Test: In the present study the method of chi-square has been used to test the relationship between 
the variables and find out the scientific conclusions. It is most widely used test of significance in social sciences. It is also called test of independence.

To test the relationship between variables two types of hypothesis were generated. The first is null hypothesis or hypothesis of no difference. It shows the independence of variables $\left(\mathrm{H}_{0}\right)$. The second hypothesis is called alternative hypothesis, which is the research hypothesis symbolized by $\mathrm{H}_{1}$.

Gamma Test: Gamma coefficient is also a statistical test that was used to measure the relationship between the variables. Computational technique for evaluating gamma is given below:

$\mathrm{Ns}-\mathrm{Nd}$
$\mathrm{Gamma}=$
$\mathrm{Ns}+\mathrm{Nd}$

\subsection{Multiple Linear Regression Analysis}

Regression is used to see the influence of the independent variable on dependent variable. If there is one independent and one dependent variable in the regression model the regression is called simple regression, whereas if there are more than one independent variable in regression model then the regression is called multiple regressions.

\section{Results and Discussions}

Bivariate analysis explains the interaction between explanatory and response variables. The strength of relationship is checked by the chi-square and gamma statistics. This relationship might be significant or non-significant. Bi-variate analyses showing the relationship between two variables were described as under:

4.1 Research Hypothesis 1: Higher the educational status of the respondents, higher will be familiarity with the importance of life insurance

Table 01: Association between the educational status and importance of life insurance

\begin{tabular}{|c|c|c|c|c|c|}
\hline \multirow{2}{*}{\multicolumn{2}{|c|}{ Educational Status of the respondents }} & \multicolumn{3}{|c|}{ Importance of life insurance } & \multirow{2}{*}{ Total } \\
\hline & & \multirow{2}{*}{$\begin{array}{c}\text { To great extent } \\
12 \\
8.6 \%\end{array}$} & \multirow{2}{*}{$\begin{array}{c}\text { To some extent } \\
2 \\
1.4 \%\end{array}$} & \multirow{2}{*}{$\begin{array}{c}\text { Not at all } \\
1 \\
.7 \%\end{array}$} & \\
\hline Illiterate & $\begin{array}{c}\text { Count } \\
\% \text { of Total }\end{array}$ & & & & $\begin{array}{c}15 \\
10.7 \%\end{array}$ \\
\hline Elementary & $\begin{array}{c}\text { Count } \\
\% \text { of Total }\end{array}$ & $\begin{array}{c}10 \\
7.1 \%\end{array}$ & $\begin{array}{c}2 \\
1.4 \%\end{array}$ & $\begin{array}{c}1 \\
.7 \%\end{array}$ & $\begin{array}{c}13 \\
9.3 \%\end{array}$ \\
\hline SSC \& HSSC & $\begin{array}{c}\text { Count } \\
\% \text { of Total }\end{array}$ & $\begin{array}{c}52 \\
37.1 \%\end{array}$ & $\begin{array}{c}2 \\
1.4 \%\end{array}$ & $\begin{array}{c}1 \\
.7 \% \\
\end{array}$ & $\begin{array}{c}55 \\
39.3 \% \\
\end{array}$ \\
\hline Graduation & $\begin{array}{c}\text { Count } \\
\% \text { of Total }\end{array}$ & $\begin{array}{c}1 \\
.7 \% \\
\end{array}$ & $\begin{array}{c}29 \\
20.7 \% \\
\end{array}$ & $\begin{array}{c}9 \\
6.4 \% \\
\end{array}$ & $\begin{array}{c}39 \\
27.9 \% \\
\end{array}$ \\
\hline Post graduation & $\begin{array}{c}\text { Count } \\
\% \text { of Total }\end{array}$ & $\begin{array}{c}1 \\
.7 \% \\
\end{array}$ & $\begin{array}{c}13 \\
9.3 \%\end{array}$ & $\begin{array}{c}4 \\
2.9 \%\end{array}$ & $\begin{array}{c}18 \\
12.9 \%\end{array}$ \\
\hline Total & $\begin{array}{c}\text { Count } \\
\% \text { of Total }\end{array}$ & $\begin{array}{c}76 \\
54.3 \%\end{array}$ & $\begin{array}{c}48 \\
34.3 \%\end{array}$ & $\begin{array}{c}16 \\
11.4 \%\end{array}$ & $\begin{array}{c}140 \\
100.0 \%\end{array}$ \\
\hline
\end{tabular}

Chi-Square $=102.102 \quad$ D.F $=8$ Significance $=0.000^{* *}$

Gamma $=0.743$ Significance $=0.000^{\star \star * *}=$ Highly Significant

Table 01 depicts the Association between the educational status and importance of life insurance and the value of ChiSquare and Gamma reflect the highly significant association between the independent and dependent variables. Therefore, the research hypothesis "Higher the educational status of the respondents, higher will be familiarity with the importance of life insurance" is accepted. Similar results were found by Roy and Vishal (2007) who expressed that the main reason for the purchase of life insurance is to provide financial security for the family. There is more to it, however; people also buy life insurance as a medium to long-term tax favored savings and investment vehicle. Life insurance is fast emerging as an important mechanism to finance the needs of the people. The need for an insurance system that works on the basic principle of pooling of risks of unexpected costs of persons falling ill and needing hospitalization by 
charging premium from a wider population base of the same community. With improved literacy, modest rise in incomes, and rapid spread of print and electronic media, there is greater awareness and increasing demand for better services of insurance.

4.2 Research Hypothesis 2: Nexuses between religious school of thoughts and insurance companies may likely for improvement of insurance policy

Table 02: Coordination between religious school of thoughts and insurance companies for the improvement of insurance policy

\begin{tabular}{|c|c|c|c|c|c|}
\hline \multirow{2}{*}{\multicolumn{2}{|c|}{$\begin{array}{l}\text { Coordination between religious school of thoughts and } \\
\text { insurance companies }\end{array}$}} & \multicolumn{3}{|c|}{$\begin{array}{l}\text { Improvements in policies of insurance } \\
\text { company }\end{array}$} & \multirow[t]{2}{*}{ Total } \\
\hline & & To great extent & To some extent & Not at all & \\
\hline \multirow{2}{*}{ Yes } & Count & 52 & 63 & 4 & 119 \\
\hline & $\%$ of Total & $37.1 \%$ & $45.0 \%$ & $2.9 \%$ & $85.0 \%$ \\
\hline \multirow{2}{*}{ No } & Count & 3 & 3 & 15 & 21 \\
\hline & $\%$ of Total & $2.1 \%$ & $2.1 \%$ & $10.7 \%$ & $15.0 \%$ \\
\hline \multirow{2}{*}{ Total } & Count & 55 & 66 & 19 & 140 \\
\hline & $\%$ of Total & $39.3 \%$ & $47.1 \%$ & $13.6 \%$ & $100.0 \%$ \\
\hline
\end{tabular}

Chi-Square $=70.526$ D.F $=2$ Significance $=0.000^{* *}$

Gamma $=0.797$ Significance $=0.000^{\star \star * *}=$ Highly Significant

Table 02 reflects the Association between the religious school and needs for improvements in polices of insurance companies and the value of Chi-Square and Gamma reflect the highly significant association between the independent and dependent variables. Therefore, the research hypothesis "Nexuses between religious school of thoughts and insurance companies may likely for improvement of insurance policy" is accepted.

\subsection{Multivariate Analysis}

Bivariate analysis is frequently explains the relation between two variable and the multivariate analysis explains the connection between the one response variable and two or more explanatory variables (Panneerselvam, 2005). In this research, to check the effects of independent variables on the response variable multiple regression analysis was conducted. Regression model is an important method of analysis for developing cause and effect relationship between explanatory variables and response variable.

Table 03: Influence of various independent variables on dependent variable a multiple linear regression model

\begin{tabular}{|c|c|c|c|c|c|}
\hline \multirow{2}{*}{ Independent variables } & \multicolumn{2}{|c|}{ Un-standardized Coefficients } & \multirow{2}{*}{$\frac{\text { Standardized Coefficients }}{\beta}$} & \multirow{2}{*}{$t_{\text {cal. }}$} & \multirow{2}{*}{ Sig. } \\
\hline & bi & Std. Error & & & \\
\hline (Constant) & 0.336 & 0.066 & & 5.077 & $0.000^{\star *}$ \\
\hline Satisfaction level with the amount (X1) & 0.157 & 0.021 & 0.250 & 7.530 & $0.000^{\star *}$ \\
\hline Expected benefits of life insurance (X2) & 0.189 & 0.024 & 0.494 & 8.042 & $0.000^{\star \star}$ \\
\hline $\begin{array}{l}\text { Need of coordination between Religious school and } \\
\text { Insurance companies (X3) }\end{array}$ & 0.967 & 0.070 & 0.002 & 0.042 & $0.003^{\star *}$ \\
\hline Financial problem during the Policy (X4) & 0.178 & 0.062 & 0.178 & 2.867 & $0.005^{\star *}$ \\
\hline Importance of Life Insurance (X5) & 0.103 & 0.041 & 0.143 & 2.513 & $0.013^{*}$ \\
\hline Amount of Premium (X6) & 0.042 & .021 & 0.100 & 2.007 & $0.047^{*}$ \\
\hline Role of media in promotion of life insurance (X7) & -0.159 & 0.083 & -0.093 & -1.913 & $0.058^{*}$ \\
\hline
\end{tabular}

Adjusted $\mathrm{R}^{2}=0.880 \mathrm{~F}=146.653 \mathrm{D} . \mathrm{F}=7$ Significance $=0.000^{\star \star}$

Significant at 0.05 as well as $0.01 * *=$ Highly Significant $*=$ Significant

\subsubsection{Variable wise description of the Model}

The variable wise description of regression model is given below: 
The value of regression coefficient i.e. bi $=0.157$ shows a highly significant relationship with $p$-value $=0.000$ for the variable "satisfaction with the amount they get after completion of policy" indicated that satisfaction level with the amount they get after completion caused 0.1576 point increase favorable attitude formation towards life insurance and decrease the complication in insurance policies. The highly significant $P$-value $=0.000$ for the regression coefficient $b i=0.189$, for the variable "expected benefits from life insurance" that increase the rate of policies if they get more benefits i.e. favorable attitude towards life insurance at least 0.189 points. The value of regression coefficient bi=0.967 shows the highly significant influence on dependent variable with $p$-value $=0.003$ for the variable "Coordination between Religious school and insurance companies" that increase the 0.967 points in the response variable. That means the coordination between religious school and insurance companies increased the policies rate and people purchase more polices, so the complications on insurance companies decrease because people show favorable attitude towards insurance. The highly significant $p$-value $=0.005$ with regression coefficient $\mathrm{bi}=0.178$ for the variable "Financial problems" shows a strong relationship that increase the complications of insurance companies because the financial problems are the hurdle in the way of selling polices. It is concluded that financial problem increased the complication of insurance companies 0.178 points more. The value of $b i=0.103$ with $p$-value $=0.013$ for the variable "importance of life insurance" increased in favorable attitude formation towards insurance the state caused 0.103 point increase. This shows that if the people become aware with the importance of life insurance in their lives than they shows more favorable attitude for insurance. The value of bi=0.042 with $p$-value 0.047 for the variable "amount of premium" caused an increase of 0.047 in the dependent variable. The result shows that the amount of premium is very important to get benefits after the completion of policy of the policy holder as well as for companies, because the large amount give big benefits that insurance companies used in future for the attitude formation of people towards insurance. The $p$-value 0.058 with regression coefficient bi=0.159 for the variable "role of media" caused increase 0.058 point in response variable. The inference shows that there is a negative relationship between the variables because if the media make a proper campaign for the insurance it will give positive results as well as media campaign is negative than the rate insurance policies might be reduced.

\section{Conclusion}

In the light of the results of the present study the following conclusions are drawn:

a) The GDP of Pakistan is contributed only $0.23 \%$ by the insurance industry. Total Premium of Pakistan insurance industry was \$ 949 million in 2006, whereas in India it was \$43,032 million. In Pakistan, total number of policy holders was about 13.6 million in 2011 , or about $7.8 \%$ of the total population.

b) People have rigid religious beliefs; and hesitate to buy policy. About $67.5 \%$ of population is living in rural societies and $73.6 \%$ are living below the poverty line. As a consequence of less income, low rate of literacy jointly with strict religious beliefs, insurance industry in Pakistan could not develop as compared to other countries of subcontinent e.g. Sri Lanka and India.

c) Insurance companies have complicated rules and regulations in terms of the understanding of general public as they could not able to approach the actual status of life insurance policy. Insurance companies in Pakistan actually depend upon their field force to communicate about all its insurance policies and to deliver all information regarding life insurance plans. Most of the time the field force staff provide fake information to the policy holder.

d) The insurance companies generally have no such criteria of hiring their field force employees in terms of certain level of education, training and experience. The overall reliability on the field force staff with less educational background makes most of the community anxious from the insurance policies.

So, the life insurance sector is not as flourishing as in other developed even in developing countries and a limited number of people are availing the benefits of life insurance.

\section{References}

Aggarwal, M. (2005). "The Different Types of Life Insurance" Online at: http://ezinearticles.com/?The-Different-Types-of-LifeInsuranceExplained\&id=116463 (Accessed 22 August 2012).

Akhter, W. (2009). "Potential of Takāful in Pakistan: Operational and transformational paradigm". A published thesis of (PhD).Department of management sciences National University of Modern Languages Islamabad.

Ahuja, R. (2012). "Why People Aren't Buying Life Insurance". Online at: http://clubthrifty.com/why-people-arent-buying-life-insurance/ (Accessed Jul 10, 2013).

Ahmad, I. (2012). "Social Safety Nets"; Economic Survey of Pakistan 2011-12.

Nida, (2012). "Life insurance offers a safe future". Online at: http://www.mustinsuredlife.blogspot.com/ (Accessed 14 September 2012). 
Mcmaken, L. (2012). "Types of Insurance everyone needs" by Linda McMaken February 15, 2012 Available online: http://www. investopedia.com/financial-edge/0212/4-types-of-insurance-everyone-needs.aspx\#ixzz1JCyKf3pk (Accessed 26 August 2012).

Bhartiaxa, A. (2009). "The benefits and Importance of Life Insurance Policies". Online at: http://www.traderji.com/insurance/25786benfits-importance-life-insurance-policies.html (Accessed 12 September 2012).

Gala, K. (2012). "Term insurance vs endowment plan: Which benefits you more?" Available at:http://www.rediff.com/getahead/slideshow/slide-show-1-money-term-insurance-vs-endowment-plan-which-benefits-you-more/20120519.htm\#1 (Accessed Feb 21, 2013).

Government of Pakistan (1998 ). Population and Housing Census of Pakistan, 1998: Census Bulletin-1. Population Census Organization, Statistics Division, Islamabad, p.2-3.

Mesum, S. A. (2008). "Insurance Industry of Pakistan approaching victory", The Nation. http://www.nation.com.pk/pakistan-newsnewspaper-daily-english-online/business/14-Apr-2008/Insurance-Industry-of-Pakistan-approaching-victory (Accessed 16 August 2012).

Panneerselvam, R. (2005). "Research Methodology", Prentice-Hall of India private limited New Delhi

Pareto, C. (2012). "Intro to Insurance: Types of Life Insurance" by Cathy Pareto 2012. Online at: http://www.investopedia.com/university/ insurance/insurance8.asp\#ixzz1LasHateO (Accessed 11 August 2012).

Roy, S. And Vishal. (2007). "Dynamics of Private Sector General Insurance in India" A Case Study AIMS International Vol. 1, No.3, pp. 175-188

Sigma. (2006). "World insurance in 2005: moderate premium growth, attractive Profitability", Swiss Reinsurance Company, Economic Research and Consulting, Switzerland.

State Life Insurance Corporation Pakistan. (2012). "Endowment Assurance" presented by State Life Insurance Corporation Pakistan. Available at: http://www.statelife.com.pk/html/endowment_assurance.cfm (Accessed 13 Feb 2013).

Tirmizi, F. (2012). "Why Pakistan's life insurance business is taking off?" Published in The Express Tribune, October 22nd, 2012. 